\title{
Inorganic Chemistry of Water and Bed Sediment in Selected Tributaries of the South Umpqua River, Oregon, 1998
}

By STEPHEN R. HINKLE

U.S. GEOLOGICAL SURVEY

Water-Resources Investigations Report 99-4196

Prepared in cooperation with

DOUGLAS COUNTY, OREGON 


\title{
U.S. DEPARTMENT OF THE INTERIOR BRUCE BABBITT, Secretary
}

\author{
U.S. GEOLOGICAL SURVEY \\ Charles G. Groat, Director
}

The use of trade, product, or firm names in this publication is for descriptive purposes only and does not imply endorsement by the U.S. Government.

For additional information write to:

District Chief

U.S. Geological Survey, WRD 10615 S.E. Cherry Blossom Drive Portland, OR 97216-3159

E-mail: info-or@usgs.gov
Copies of this report can be purchased from:

U.S. Geological Survey

Branch of Information Services

Box 25286

Denver, CO 80225-0286

E-mail: infoservices@usgs.gov

Information regarding the U.S. Geological Survey, Water Resources Division, Oregon District activities is available at <http://oregon.usgs.gov/> 


\section{CONTENTS}

Abstract

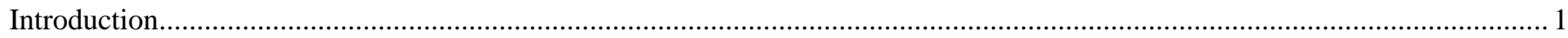

Purpose and Scope

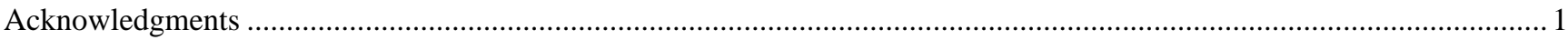

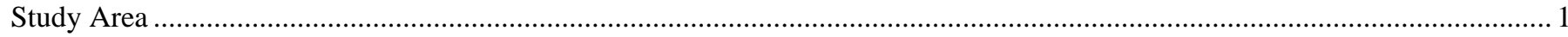

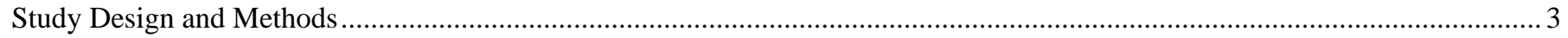

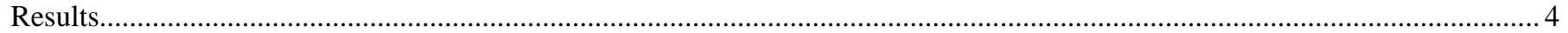

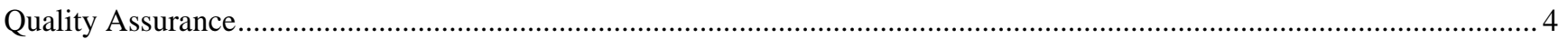

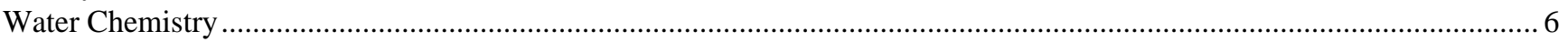

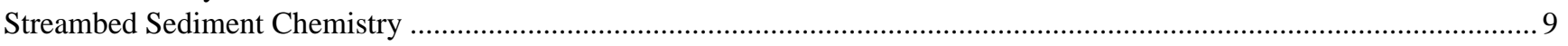

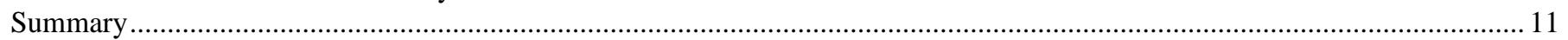

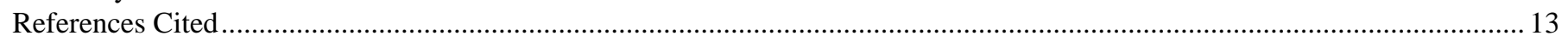

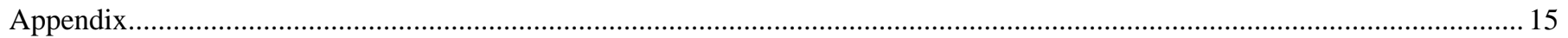

\section{FIGURES} 1. Map showing locations of sampling sites in the South Umpqua Basin, Oregon, 1998 ………...........................................2

\section{TABLES}

1. Sampling sites, locational data, dates sampled, and general characteristics of sites sampled in the

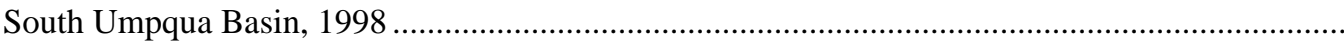

2. Field-equipment-blank and standard-reference-sample concentrations in aqueous quality-control samples analyzed for major and minor ions and nutrients .......................................................................................

3. Field-equipment-blank and standard-reference-sample concentrations in aqueous quality-control samples analyzed for trace elements.

. Field parameters and major-ion, minor-ion, and nutrient concentrations for aqueous environmental samples

5. Trace-element concentrations for aqueous environmental samples .

environmental samples

7. Comparison between streambed-sediment concentrations and Canadian sediment quality guidelines for the protection of aquatic life

8. Comparison between streambed-sediment concentrations from this study and break-point values for streambed sediment in the Willamette Basin.....

\section{CONVERSION FACTORS}

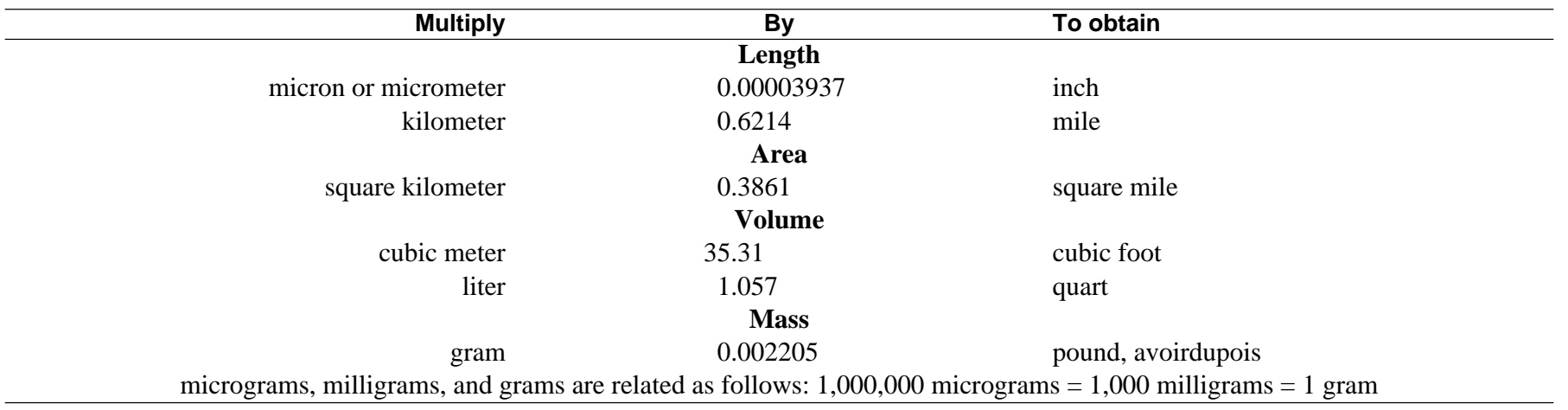

Temperature in degrees Celsius $\left({ }^{\circ} \mathrm{C}\right)$ may be converted to degrees Fahrenheit $\left({ }^{\circ} \mathrm{F}\right)$ as follows: ${ }^{\circ} \mathrm{F}=1.8^{\circ} \mathrm{C}+32$ 



\title{
Inorganic Chemistry of Water and Bed Sediment in Selected Tributaries of the South Umpqua River, Oregon, 1998
}

\author{
By Stephen R. Hinkle
}

\section{ABSTRACT}

Ten sites on small South Umpqua River tributaries were sampled for inorganic constituents in water and streambed sediment. In aqueous samples, high concentrations (concentrations exceeding U.S. Environmental Protection Agency criterion continuous concentration for the protection of aquatic life) of zinc, copper, and cadmium were detected in Middle Creek at Silver Butte, and the concentration of zinc was high at Middle Creek near Riddle. Similar patterns of trace-element occurrence were observed in streambed-sediment samples.

The dissolved aqueous load of zinc carried by Middle Creek along the stretch between the upper site (Middle Creek at Silver Butte) and the lower site (Middle Creek near Riddle) decreased by about 0.3 pounds per day. Removal of zinc from solution between the upper and lower sites on Middle Creek evidently was occurring at the time of sampling. However, zinc that leaves the aqueous phase is not necessarily permanently lost from solution. For example, zinc solubility is $\mathrm{pH}$-dependent, and a shift between solid and aqueous phases towards release of zinc to solution in Middle Creek could occur with a perturbation in stream-water $\mathrm{pH}$. Thus, at least two potentially significant sources of zinc may exist in Middle Creek: (1) the upstream source(s) producing the observed high aqueous zinc concentrations and (2) the streambed sediment itself (zinc-bearing solid phases and/or adsorbed zinc). Similar behavior may be exhibited by copper and cadmium because these trace elements also were present at high concentrations in streambed sediment in the Middle Creek Basin.

\section{INTRODUCTION}

Impacts on the quality of stream water and bed sediment in the South Umpqua Basin from naturally occurring geologic ore deposits and current and abandoned mining operations have not been well characterized. Release of trace elements or acidic water from ore deposits or mining sites could result in degradation of wildlife habitat or water quality, or result in toxic effects.
The need to characterize impacts from ore deposits and mining operations on downstream water and streambedsediment quality in the South Umpqua Basin led to a cooperative reconnaissance investigation of inorganic chemical characteristics of water and streambed sediment by the U.S. Geological Survey (USGS) and Douglas County, Oregon, in 1998.

\section{Purpose and Scope}

This report presents results of an investigation of water and streambed-sediment quality in selected tributaries of the South Umpqua River. Concentrations of inorganic constituents in water (major and minor ions, nutrients, and trace elements) and streambed sediment (primarily trace elements), along with standard field parameters, are tabulated for samples collected at 10 sites. Aqueous trace-element concentrations are compared with U.S. Environmental Protection Agency (USEPA) criterion continuous concentrations for the protection of aquatic life (U.S. Environmental Protection Agency, 1998). Streambed-sediment trace-element concentrations are compared with Canadian sediment quality guidelines for the protection of aquatic life (Environment Canada, 1998) and, to provide a frame of reference, with previously collected streambed-sediment data from the Willamette Basin in western Oregon.

\section{Acknowledgments}

Lowell Duell (U.S. Bureau of Land Management [BLM]) provided guidance with site selection and overall project logistical and field support. Eric Heenan (BLM) also provided guidance with site selection. Field support for sample collection and processing from the following BLM personnel is gratefully acknowledged: Aimee Hoefs, Dan Cressy, Ed Horn, Rob Hurt, Todd Kuck, Rich Pastor, Ed Rumbold, and Mike Rustay.

\section{STUDY AREA}

The study area (fig. 1) consists of portions of the South Umpqua Basin. Most study-area streams drain areas of the Klamath Mountains geologic province (Orr and others, 1992). Some streams in the study area also drain volcanic rocks of the Cascade Range. 


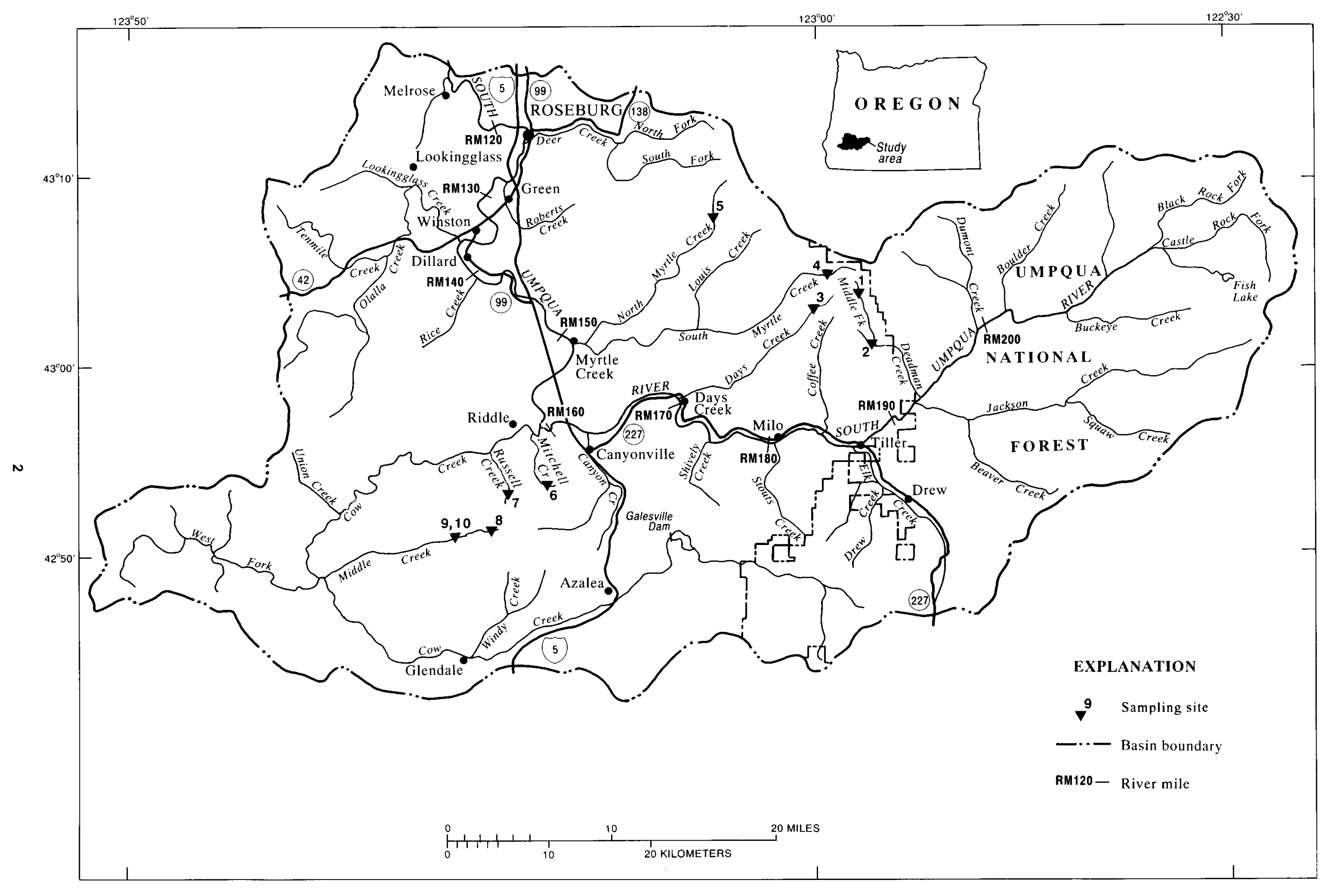

Figure 1. Locations of sampling sites in the South Umpqua Basin, Oregon. (See table 1 for map number location.) 
The Klamath Mountains geologic province is composed of a complex assemblage of accreted exotic terrains, including oceanic crust and island archipelago environments. Following accretion to the continent, these terrains were intruded by granitic rocks. Mineralization in the Klamath Mountains geologic province resulted from processes associated with sea floor spreading and with later intrusion of granitic rocks. For example, hypogene sulfides mined at Silver Butte (in the Middle Creek Basin; fig. 1) are thought to have resulted from processes associated with intrusion of granitic rocks (Shenon, 1933). Cascadian rocks in the study area are primarily tuffaceous rocks and basaltic lava.

\section{STUDY DESIGN AND METHODS}

Ten sites on small streams in the South Umpqua Basin (fig. 1) were sampled during low-flow conditions in August and September 1998. Effects of stormflows on trace element mobilization would not be captured during low-flow conditions, but dilution effects on dissolved trace-element concentrations would be expected to be minimized during low flows. The streams drain areas containing natural ore deposits and/or mining sites. The sampling sites are described in table 1 .

Table 1. Sampling sites, locational data, dates sampled, and general characteristics of sites sampled in the South Umpqua Basin, 1998

[Fk, fork; Cr, creek; Nr, near; OR, Oregon; latitude and longitude given in ${ }^{\circ}($ degrees), '(minutes), and "(seconds); E, estimated; S, south; N, north; BLM, Bureau of Land Management; drainage area and geological site characteristics supplied by Lowell Duell (U.S. Bureau of Land Management, written commun., 1999)]

\begin{tabular}{|c|c|c|c|c|c|c|c|}
\hline $\begin{array}{l}\text { Map } \\
\text { no. }\end{array}$ & $\begin{array}{l}\text { Site } \\
\text { name }\end{array}$ & Latitude & Longitude & $\begin{array}{c}\text { Date } \\
\text { sampled }\end{array}$ & $\begin{array}{l}\text { Instantaneous } \\
\text { stream } \\
\text { discharge } \\
\text { (cubic feet } \\
\text { per second) }\end{array}$ & $\begin{array}{l}\text { Drainage area } \\
\text { (square miles) }\end{array}$ & $\begin{array}{l}\text { General geological } \\
\text { site characteristics }\end{array}$ \\
\hline 1 & $\begin{array}{l}\text { Middle Fk } \\
\text { Deadman Cr Nr } \\
\text { Myrtle Creek, OR }\end{array}$ & $43^{\circ} 04^{\prime} 06^{\prime \prime}$ & $122^{\circ} 56^{\prime} 51^{\prime \prime}$ & 08-26-1998 & E. 3 & 0.76 & Mineralized; negligible mining activity. \\
\hline 3 & $\begin{array}{l}\text { Days Cr Nr } \\
\text { Days Creek, OR }\end{array}$ & $43^{\circ} 03^{\prime} 13^{\prime \prime}$ & $123^{\circ} 00^{\prime} 09^{\prime \prime}$ & 09-17-1998 & E.2 & 3.4 & Mineralized; negligible mining activity. \\
\hline 6 & $\begin{array}{l}\text { Mitchell } \mathrm{Cr} \mathrm{Nr} \\
\text { Canyonville, OR }\end{array}$ & $42^{\circ} 53^{\prime} 45^{\prime \prime}$ & $123^{\circ} 19^{\prime} 32^{\prime \prime}$ & 08-25-1998 & .028 & 0.37 & Mineralized; no mining activity. \\
\hline 7 & $\begin{array}{l}\text { Russell Cr } \\
\text { Nr Riddle, OR }\end{array}$ & $42^{\circ} 53^{\prime} 18^{\prime \prime}$ & $123^{\circ} 22^{\prime} 07^{\prime}$ & 08-27-1998 & E. 5 & 3.0 & Mineralized; historical mining activity. \\
\hline 8 & $\begin{array}{l}\text { Middle } \mathrm{Cr} \text { at } \\
\text { Silver Butte, OR }\end{array}$ & $42^{\circ} 51^{\prime} 22^{\prime \prime}$ & $123^{\circ} 23^{\prime} 31^{\prime \prime}$ & 09-14-1998 & E.07 & 0.38 & $\begin{array}{l}\text { Mineralized; substantial amount of } \\
\text { historical mining activity; high priority site } \\
\text { for the BLM abandoned mine inventory. }\end{array}$ \\
\hline 9 & $\begin{array}{l}\text { S Fk Middle Cr } \\
\text { Nr Riddle, OR }\end{array}$ & $42^{\circ} 50^{\prime} 47^{\prime \prime}$ & $123^{\circ} 26^{\prime} 02^{\prime \prime}$ & 09-15-1998 & 2.8 & 6.5 & Mineralized; historical mining activity. \\
\hline
\end{tabular}

\footnotetext{
${ }^{\text {a }}$ Streambed sediment collected 08-28-98.

${ }^{\mathrm{b}}$ Site located 2.5 river miles below Middle Creek at Silver Butte site.
} 
Measurements of streamflow were made in accordance with standard USGS procedures (Rantz and others, 1982). For 5 of the 10 sites, narrow stream dimensions and small water flows resulted in greater measurement uncertainty (uncertainty $> \pm 8$ percent) than is typically observed in measurements at larger streams; for these sites, streamflows are reported to one significant figure and are labeled as estimates. Streamflows reported as estimates in this report represent quantitative measurements, but the standard error of measurement may range up to \pm 20 -30 percent.

Water samples were collected and processed using methods of Shelton (1994). Filtered samples were filtered through $0.45-\mu \mathrm{m}$ (micron or micrometer) capsule filters. Streambed sediment was collected and processed using methods of Shelton and Capel (1994). The < (less than) $62 \mu \mathrm{m}$ fraction of streambed sediment was submitted for analysis.

Water samples were analyzed at the USGS National Water Quality Laboratory (NWQL) in Arvada, Colorado. Major and minor ions were analyzed by inductively coupled plasma/atomic emission spectrometry (ICP/AES) (calcium, iron, magnesium, manganese, silica, sodium), ion-exchange chromatography (chloride, sulfate), atomic absorption spectrometry (potassium), and with an ion-selective electrode (fluoride). Nutrients were measured colorimetrically. Trace elements were measured by inductively coupled plasma/mass spectrometry (ICP/MS) (aluminum, antimony, barium, beryllium, cadmium, chromium, cobalt, copper, lead, manganese, molybdenum, nickel, silver, uranium, zinc), graphite furnace-atomic absorption spectrometry (selenium), and hydride generation-atomic absorption spectrometry (arsenic). Note that manganese was analyzed by both ICP/AES (part of major- and minor-ion suite) and by ICP/MS (part of trace-element suite). Analytical methods are described in Faires (1993), Fishman (1993), Fishman and Friedman (1989), and Jones and Garbarino (1999).

Streambed-sediment samples were analyzed for a suite of 48 constituents by the USGS Analytical Chemistry Services Group Laboratory (ACSGL) in Denver, Colorado. Analytical methods are described in Arbogast (1996) and Briggs and Meier (1999).

Quality-control (QC) data were collected to evaluate techniques used to collect, process, and analyze water samples. QC data were collected as part of project-level (as opposed to laboratory-level) qualityassurance efforts. The NWQL internal quality-assurance program is described by Pritt and Raese (1995). ACSGL internal quality assurance is described by Arbogast (1996) and Briggs and Meier (1999).
One set of aqueous field blanks was collected to quantify sample contamination that may have occurred as a result of sample collection, processing, and analysis. After routine cleaning of field equipment used to collect samples at the chosen site, blank water of known quality was passed through the field equipment while on-site. Processing steps used for environmental samples (for example, filtering and preservation) also were evaluated by the field blanks. The environmental sample from the site chosen for the field blank happened to yield the highest trace-element concentrations of all 10 sites; hence, the field blank represented a rigorous test of methods used to clean equipment and to collect, process, and analyze samples.

Analysis of trace elements in the field equipment blank was done by a method used for low-concentration samples. The low-concentration method is similar to that used for analysis of environmental samples, but has lower method detection limits and is used by the NWQL solely for analysis of field and laboratory blanks. The low-concentration method allows detection of small concentrations of contamination (concentrations below the method detection limit for the method used for environmental samples).

One set of aqueous standard reference samples (SRSs) was submitted to quantify analytical accuracy. Trace-element and major-ion SRSs were provided by the USGS SRS program, an interlaboratory testing program. The SRS sample program and the SRSs used are described by Farrar and Long (1997). Results are compared to SRS-program most probable values (MPVs). An MPV for an analyte is the median of the concentrations determined by the participating laboratories. The nutrient SRS was made in the Oregon District Laboratory from standard materials.

Two streambed-sediment samples were split. Split samples were used to evaluate analytical reproducibility (precision).

\section{RESULTS}

Stream discharge at sampling sites is given in table 1. Quality-control and environmental data are discussed in the following sections.

\section{Quality Assurance}

Field-blank and SRS data are presented in tables 2 and 3. Field-equipment-blank concentrations demonstrate that field and laboratory methods were noncontaminating. SRS recoveries demonstrate good analytical accuracy. 
Table 2. Field-equipment-blank and standard-referencesample concentrations in aqueous quality-control samples analyzed for major and minor ions and nutrients

[mg/L, milligrams per liter; SRS, U. S. Geological Survey Standard

Reference Sample; MPV, most probable value; N/A, not available; analyses for filtered samples unless otherwise noted]

\begin{tabular}{|c|c|c|c|}
\hline & Blank & & SRS \\
\hline Constituent & $\begin{array}{c}\text { Reported } \\
\text { analytical } \\
\text { concentration } \\
(\mathrm{mg} / \mathrm{L})\end{array}$ & $\begin{array}{c}\text { MPV } \\
(\mathrm{mg} / \mathrm{L})\end{array}$ & $\begin{array}{c}\text { Reported } \\
\text { analytical } \\
\text { concentration } \\
(\mathrm{mg} / \mathrm{L})\end{array}$ \\
\hline Calcium & $<0.02$ & 60.7 & 58 \\
\hline Magnesium & $<0.1$ & 18.0 & 18 \\
\hline Sodium & $<0.1$ & 39.0 & 39 \\
\hline Potassium & $<0.1$ & 2.58 & 2.8 \\
\hline Chloride & $<0.1$ & 25.8 & 25 \\
\hline Sulfate (as $\mathrm{SO}_{4}$ ) & $<0.1$ & 150 & 150 \\
\hline Fluoride & $<0.1$ & 0.530 & 0.5 \\
\hline Silica $\left(\right.$ as $\left.\mathrm{SiO}_{2}\right)$ & $<0.1$ & 7.35 & 6.9 \\
\hline Iron & $<0.010$ & N/A & $<0.010$ \\
\hline Manganese & $<0.004$ & N/A & $<0.004$ \\
\hline Ammonia (as N) & $<0.002$ & 0.21 & 0.22 \\
\hline Nitrite (as N) & $<0.001$ & 0.000 & $<0.001$ \\
\hline $\begin{array}{l}\text { Ammonia + organic } \mathrm{N} \\
\text { (as N) }\end{array}$ & $<0.1$ & 0.21 & 0.2 \\
\hline $\begin{array}{l}\text { Ammonia + organic } \mathrm{N} \text {, } \\
\text { unfiltered (as } \mathrm{N})\end{array}$ & $<0.1$ & 0.21 & 0.2 \\
\hline $\begin{array}{l}\text { Nitrite + nitrate } \\
\text { (as N) }\end{array}$ & $<0.005$ & 0.85 & 0.83 \\
\hline $\begin{array}{l}\text { Phosphorus, } \\
\text { unfiltered (as P) }\end{array}$ & $<0.001$ & 0.086 & 0.080 \\
\hline Phosphorus (as P) & $<0.001$ & 0.086 & 0.084 \\
\hline $\begin{array}{l}\text { Orthophosphorus } \\
\text { (as P) }\end{array}$ & $<0.001$ & 0.027 & 0.028 \\
\hline
\end{tabular}

Table 3. Field-equipment-blank and standard-referencesample concentrations in aqueous quality-control samples analyzed for trace elements

$[\mu \mathrm{g} / \mathrm{L}$, micrograms per liter; SRS, U. S. Geological Survey Standard Reference Sample; MPV, most probable value]

\begin{tabular}{|c|c|c|c|}
\hline & Blank & & SRS \\
\hline Constituent & $\begin{array}{c}\text { Reported } \\
\text { analytical } \\
\text { concentration } \\
(\mu \mathrm{g} / \mathrm{L})\end{array}$ & $\begin{array}{c}\text { MPV } \\
(\mu \mathrm{g} / \mathrm{L})\end{array}$ & $\begin{array}{c}\text { Reported } \\
\text { analytical } \\
\text { concentration } \\
(\mu \mathrm{g} / \mathrm{L})\end{array}$ \\
\hline
\end{tabular}

Aluminum

$<0.3$

67.6

Antimony

$<0.2$

8.80

9

Arsenic

$<1$

9.88

9

Barium

$<0.2$

37.1

39

Beryllium

$<0.2$

9.04

9

Cadmium

$<0.3$

9.33

10

Chromium

$<0.2$

15.3

15

Cobalt

$<0.2$

10.0

10

Copper

$<0.2$

11.0

11

Lead

$<0.3$

12.7

13

Manganese

$<0.1$

20.9

20

Molybdenum

$<0.2$

9.23

9

Nickel

$<0.5$

11.0

11

Selenium

$<1$

10.1

9

Silver

$<0.2$

7.55

8

Uranium

$<0.2$

1.10

$<2$

Zinc

$<0.5$

10.0

10 
Data from split streambed-sediment samples are presented along with environmental streambed-sediment data in a later section of this report ("Streambed Sediment Chemistry"). Comparison of data from the split samples indicates good analytical precision.

\section{Water Chemistry}

Chemical data for water samples are given in tables 4 and 5. Measured $\mathrm{pH}$ values were near neutral to slightly alkaline, ranging from 7.4 to 8.1 . Most trace-element concentrations were low; more than 70 percent fell below the minimum reporting level of $1 \mu \mathrm{g} / \mathrm{L}$ (microgram per liter). However, some notable concentrations of zinc, copper, and cadmium were observed. Concentrations of zinc $(1,450 \mu \mathrm{g} / \mathrm{L})$, copper $(97 \mu \mathrm{g} / \mathrm{L})$, and cadmium $(8 \mu \mathrm{g} / \mathrm{L})$ for Middle Creek at Silver Butte all exceeded USEPA criterion continuous concentration (CCC) guidelines for the protection of aquatic life (U.S. Environmental Protection Agency, 1998). The concentration of zinc $(134 \mu \mathrm{g} / \mathrm{L})$ for Middle

Table 4. Field parameters and major-ion, minor-ion, and nutrient concentrations for aqueous environmental samples [Units of milligrams per liter unless specified otherwise; $\mathrm{Fk}$, fork; $\mathrm{Cr}$, creek; $\mathrm{Nr}$, near; $\mathrm{S}$, south; $\mathrm{N}$, north; ${ }^{\circ} \mathrm{C}$, degrees Celsius]

\begin{tabular}{|c|c|c|c|c|c|c|c|c|c|c|}
\hline $\begin{array}{l}\text { Field parameters } \\
\text { and water-quality } \\
\text { constituents }\end{array}$ & $\begin{array}{c}\text { Middle Fk } \\
\text { Deadman } \\
\text { Cr Nr } \\
\text { Myrtle Cr }\end{array}$ & $\begin{array}{l}\text { Deadman } \\
\text { Cr Nr } \\
\text { Milo }\end{array}$ & $\begin{array}{l}\text { Days } \\
\text { Cr Nr } \\
\text { Days Cr }\end{array}$ & $\begin{array}{l}\text { S Myrtle } \\
\text { Cr Nr } \\
\text { Myrtle Cr }\end{array}$ & $\begin{array}{c}\text { N Myrtle } \\
\text { Cr Nr } \\
\text { Myrtle Cr }\end{array}$ & $\begin{array}{l}\text { Mitchell } \\
\text { Cr Nr } \\
\text { Canyon- } \\
\text { ville }\end{array}$ & $\begin{array}{c}\text { Russell } \\
\text { Cr Nr } \\
\text { Riddle }\end{array}$ & $\begin{array}{c}\text { Middle } \\
\text { Cr at } \\
\text { Silver } \\
\text { Butte }\end{array}$ & $\begin{array}{c}\text { S Fk } \\
\text { Middle } \\
\text { Cr Nr } \\
\text { Riddle }\end{array}$ & $\begin{array}{c}\text { Middle } \\
\text { Cr Nr } \\
\text { Riddle }\end{array}$ \\
\hline $\begin{array}{l}\text { Temperature, water, } \\
{ }^{\circ} \mathrm{C}\end{array}$ & 10.9 & 12.8 & 13.5 & 12.6 & 16.2 & 15.4 & 13.8 & 13.2 & 12.9 & 12.3 \\
\hline Temperature, air, ${ }^{\circ} \mathrm{C}$ & 24.2 & 17.3 & 16.9 & 22.3 & 22.4 & 12.9 & 19.8 & 21.4 & 22.2 & 21.3 \\
\hline $\begin{array}{l}\text { Specific conductance, } \\
\text { microsiemens per } \\
\text { centimeter at } 25^{\circ} \mathrm{C}\end{array}$ & 77.4 & 154 & 160 & 61.8 & 187 & 250 & 160 & 404 & 146 & 248 \\
\hline Dissolved oxygen & 9.3 & 9.2 & 9.4 & 9.1 & 9.4 & 9.2 & 9.3 & 9.3 & 9.4 & 9.5 \\
\hline $\mathrm{pH}$, standard units & 7.7 & 7.6 & 7.7 & 7.4 & 8.1 & 7.8 & 8.1 & 8.0 & 8.1 & 8.0 \\
\hline Bicarbonate & 44.7 & 58.2 & 94.3 & 35.4 & 102 & 129 & 87.1 & 56.7 & 58.7 & 69.2 \\
\hline Alkalinity (as $\mathrm{CaCO}_{3}$ ) & 36.6 & 47.7 & 77.3 & 29.0 & 83.6 & 106 & 71.4 & 46.5 & 48.1 & 56.7 \\
\hline Calcium & 8.3 & 14 & 18 & 5.6 & 18 & 32 & 17 & 46 & 18 & 27 \\
\hline Magnesium & 2.3 & 4.3 & 5.8 & 1.8 & 9.2 & 9.0 & 7.3 & 17 & 5.1 & 11 \\
\hline Sodium & 4.5 & 10 & 7.7 & 4.6 & 5.0 & 5.6 & 5.0 & 6.2 & 4.9 & 5.8 \\
\hline Potassium & .9 & 1.0 & 1.0 & 1.1 & .3 & .3 & 2.4 & .6 & .4 & .5 \\
\hline Chloride & .8 & 16 & 1.5 & .9 & 3.3 & 2.9 & 2.3 & 2.7 & 2.4 & 3.1 \\
\hline Sulfate (as $\mathrm{SO}_{4}$ ) & .4 & 1.2 & 3.6 & .4 & 3.3 & 17 & 4.8 & 140 & 20 & 58 \\
\hline Fluoride & $<.1$ & $<.1$ & $<.1$ & $<.1$ & $<.1$ & $<.1$ & $<.1$ & .1 & $<.1$ & $<.1$ \\
\hline Silica (as $\mathrm{SiO}_{2}$ ) & 18 & 15 & 15 & 15 & 23 & 15 & 16 & 16 & 20 & 16 \\
\hline Iron & $<.010$ & $<.010$ & $<.010$ & $<.010$ & .015 & $<.010$ & $<.010$ & $<.010$ & .028 & $<.010$ \\
\hline Manganese & $<.004$ & $<.004$ & $<.004$ & $<.004$ & .007 & $<.004$ & $<.004$ & .007 & .009 & .005 \\
\hline Ammonia (as N) & $<.002$ & $<.002$ & $<.002$ & $<.002$ & $<.002$ & $<.002$ & $<.002$ & $<.002$ & .004 & $<.002$ \\
\hline Nitrite (as N) & $<.001$ & .003 & .001 & $<.001$ & $<.001$ & $<.001$ & $<.001$ & .001 & .001 & .003 \\
\hline $\begin{array}{l}\text { Ammonia + organic } \mathrm{N} \\
(\text { as } \mathrm{N})\end{array}$ & $<.1$ & $<.1$ & $<.1$ & $<.1$ & $<.1$ & $<.1$ & $<.1$ & $<.1$ & $<.1$ & $<.1$ \\
\hline $\begin{array}{l}\text { Ammonia + organic } \mathrm{N} \text {, } \\
\text { unfiltered (as } \mathrm{N} \text { ) }\end{array}$ & $<.1$ & $<.1$ & $<.1$ & $<.1$ & $<.1$ & $<.1$ & $<.1$ & $<.1$ & $<.1$ & $<.1$ \\
\hline $\begin{array}{l}\text { Nitrite + nitrate } \\
\text { (as } \mathrm{N})\end{array}$ & .013 & .020 & .019 & .024 & .008 & .007 & .059 & .10 & .046 & .075 \\
\hline $\begin{array}{l}\text { Phosphorus, } \\
\text { unfiltered (as P) }\end{array}$ & .014 & .020 & .033 & .008 & .011 & .006 & .012 & $<.001$ & .007 & .004 \\
\hline Phosphorus (as P) & .010 & .020 & .032 & .007 & .010 & .005 & .010 & .001 & .004 & .005 \\
\hline Orthophosphorus (as P) & .006 & .018 & .027 & .004 & .008 & .004 & .007 & $<.001$ & .003 & .003 \\
\hline
\end{tabular}


Creek near Riddle also exceeded the USEPA CCC guideline. The USEPA CCC is defined as "an estimate of the highest concentration of a material in surface water to which an aquatic community can be exposed indefinitely without resulting in an unacceptable effect" (U.S. Environmental Protection Agency, 1998). USEPA CCCs are listed in the Appendix.

Because zinc concentrations in Middle Creek were unusually high relative to concentrations observed at other sampled sites, the geochemistry of zinc in Middle
Creek is herein given brief examination. To facilitate an understanding of the possible movement and fate of zinc in Middle Creek, geochemical calculations were made using the geochemical computer program WATEQ4F (Ball and Nordstrom, 1991).

Using aqueous geochemical data (concentrations of constituents, $\mathrm{pH}$, and water temperature) and thermodynamic data for solid phases (minerals and amorphous solids), WATEQ4F calculates a theoretical distribution of aqueous species and solid-phase saturation indices.

Table 5. Trace-element concentrations for aqueous environmental samples

[Units of micrograms per liter; Fk, fork; $\mathrm{Cr}$, creek; $\mathrm{Nr}$, near; S, south; N, north]

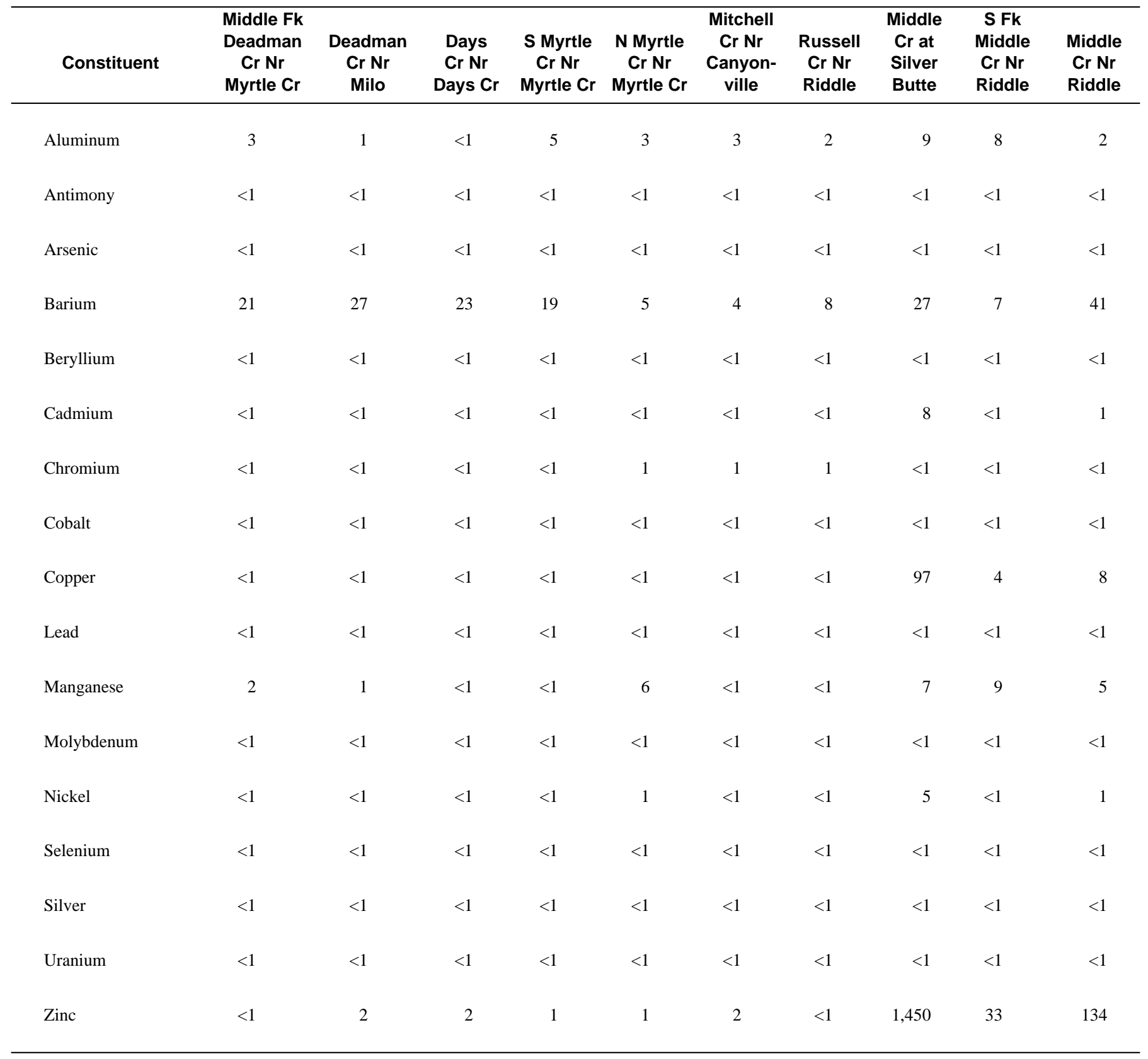


The saturation index (SI) indicates the thermodynamic direction in which reaction between aqueous and solid phases will proceed. A positive SI represents a condition in which a solid phase would be expected to precipitate from aqueous solution. A negative SI represents a condition in which a solid phase would be expected to dissolve. Mathematical definition of the SI is given in Ball and Nordstrom (1991).

Two general limitations of geochemical calculations are (1) calculations may be greatly affected by uncertainty in both the analytical and the thermodynamic data, and (2) the SI indicates the theoretical direction of reaction, but does not provide information about reaction kinetics. Importantly, the time scale over which a thermodynamically favorable reaction proceeds towards equilibrium may range from minutes to years. An additional limitation to geochemical calculations using the data collected in this study is that these data were collected by filtering samples through $0.45-\mu \mathrm{m}$ filters. Geochemical calculations generally are based on dissolved trace-element concentrations. Samples filtered through $0.45-\mu \mathrm{m}$ filters may contain trace elements in colloidal form and other nondissolved trace elements, and thus may not represent truly dissolved trace-element concentrations.

The dissolved aqueous load of zinc (operationally defined as the product of stream discharge and zinc concentration in filtered water) carried by Middle Creek along the stretch between the upper site (Middle Creek at Silver Butte) and the lower site (Middle Creek near Riddle) decreased from about 0.5 pounds per day at the upper site to 0.2 pounds per day at the lower site. Removal of zinc from solution between the upper and lower sites on Middle Creek (by solid-phase precipitation or adsorption) evidently occurred. (Downstream dilution by accumulation of flow would affect the concentration of zinc but not the load of zinc.) The load calculations indicate that about 0.3 pounds of zinc per day (with a standard error of \pm 0.2 pounds of zinc per day) were being removed from the water column in the stretch of Middle Creek between the two sites at the time of sampling. Consistent with these calculations, a white precipitate was observed on the streambed at the upper site. This precipitate was not observed at any of the other sites sampled. It is possible that this precipitate was a zinc mineral or zinc-bearing amorphous solid. Also consistent with these calculations and observations, the streambed sediment was greatly enriched with zinc compared with streambed sediment at the other nine sites (as discussed later).

Zinc leaving the aqueous phase cannot be assumed to have been permanently lost from solution.
For example, zinc solubility is $\mathrm{pH}$-dependent. The solubility of zinc minerals generally increases as $\mathrm{pH}$ decreases below near-neutral $\mathrm{pH}$ values (Hem, 1972). Geochemical calculations can be used to demonstrate this aspect of zinc geochemistry. For example, geochemical calculations for Middle Creek at Silver Butte yield an SI of +2.0 for the zinc mineral willemite $\left(\mathrm{Zn}_{2} \mathrm{SiO}_{4}\right)$, a white mineral known to occur as a secondary mineral (a mineral formed later than the primary minerals in adjacent rocks and sediment) (Klein and Hurlbut, 1985, p. 373). An SI of +2.0 suggests conditions favorable for precipitation of willemite. (For comparison, results of geochemical calculations for the lower site yield an SI of -0.2 for willemite. This SI represents a system that was close to equilibrium, but slightly undersaturated, with respect to willemite.) Nonetheless, the white precipitate observed on the streambed at the upper site was not identified by mineralogical techniques, and its identity remains unknown. It could have been another zinc-bearing solid phase or a non-zinc-bearing phase. Willemite is given consideration merely as an example of the type of changes that can occur in aqueous/solid-phase mixtures when geochemical conditions change.

To continue with these theoretical calculations, water from Middle Creek at Silver Butte would have become undersaturated with respect to willemite with a drop in $\mathrm{pH}$ from the measured value of 8.0 to a value below 7.45. Thus, although Middle Creek at Silver Butte may have been supersaturated with respect to willemite at the time of sampling, geochemical calculations suggest that the apparent supersaturation of willemite would have been reversed by a change in $\mathrm{pH}$ of less than one $\mathrm{pH}$ unit. Similar patterns of $\mathrm{pH}$-induced changes in stability would be expected for other zinc solid phases. Furthermore, zinc adsorbed onto solid-phase surfaces will tend to desorb with decreases in $\mathrm{pH}$ (Stumm and Morgan, 1996). Thus, a sufficient decrease in $\mathrm{pH}$ might have had the effect of shifting the balance between solid and aqueous phases towards release of zinc to solution in Middle Creek at Silver Butte. Such phenomena have been documented elsewhere. For example, aqueous zinc concentrations in the Clark Fork River in Montana have been observed to vary diurnally by a factor of three in response to photosynthetically driven variations in $\mathrm{pH}$ (Brick and Moore, 1994). The implication is that at least two potentially significant sources of zinc may exist at times in Middle Creek: (1) the upstream source(s) producing the observed high aqueous zinc concentrations (probably mine or tailings leachate or mineralized bedrock) and (2) the streambed sediment itself (zinc-bearing solid phases and/or adsorbed zinc). 


\section{Streambed Sediment Chemistry}

Streambed sediment data are presented in table 6 (p. 10). Mirroring patterns observed in aqueous samples, streambed-sediment concentrations of zinc, copper, and cadmium for Middle Creek at Silver Butte were elevated relative to concentrations at other sampled sites. Streambed-sediment concentrations of zinc, copper, and cadmium were about two orders of magnitude greater for Middle Creek at Silver Butte than for most other sites sampled. Concentrations of other trace elements (for example, lead and mercury) also were elevated at Middle Creek at Silver Butte compared with concentrations at other sites. Also of note, the concentration of zinc in the streambed sediment at this site $(11,000 \mu \mathrm{g} / \mathrm{gram})$ is consistent with the implications of zinc solid-phase precipitation at this site, as discussed in the previous section.

Streambed-sediment concentrations are compared against Canadian sediment quality guidelines for the protection of aquatic life (Environment Canada, 1998) in table 7 (p. 12). These comparisons are made to provide perspective for evaluation of the streambedsediment data. Note that although USEPA streambedsediment screening values have been established (U.S. Environmental Protection Agency, 1997), the Canadian guidelines represent a more appropriate point of reference for the USGS data. This is because Canadian guidelines are based on an analytical procedure using total sediment digestion (as is the analytical procedure used by the USGS), whereas USEPA screening values are based on an analytical procedure using a partial sediment digestion (L. H. Nowell, U.S. Geological Survey, written commun., 1999). The utility of comparing values obtained in this study to the Canadian guidelines or USEPA screening values is somewhat limited because neither Canadian guidelines nor USEPA screening values are based on analysis of sieved sediment. Sieved aliquots, being composed of fine-grained sediment, often are enriched in trace elements relative to unsieved samples (Horowitz and Elrick, 1987). Thus, samples analyzed in this study might exceed guidelines more frequently and to a greater degree, than would unsieved samples. By producing relatively uniform media, sieving does facilitate intersite comparisons, but sieving also may create a positive bias in trace-element concentrations.

Streambed sediment from Middle Creek at Silver Butte exceeded, often by a large margin, six of the seven established Canadian guidelines for trace elements. Concentrations of zinc, copper and cadmium at Middle Creek near Riddle and at South Fork Middle Creek near Riddle exceeded Canadian guidelines by well over an order of magnitude. Concentrations of chromium and copper in streambed sediment exceeded Canadian guidelines at all sites sampled, whereas guidelines for lead were not exceeded at any of the sites sampled.

South Umpqua Basin streambed-sediment data were compared with streambed-sediment data from the Willamette Basin in Western Oregon to provide another frame of reference for the South Umpqua Basin data. In table 8 (p. 12), South Umpqua streambed-sediment concentrations are compared against break-point concentrations for trace elements in streambed sediment calculated for a set of 52 samples from the Willamette Basin (Rinella, 1998). Break-point concentrations for a set of data represent a threshold concentration below which concentrations appear to represent background concentrations, and above which concentrations appear to represent enriched concentrations where enrichment may be anthropogenic or natural in origin. Break-point concentrations for the 52 Willamette Basin samples were used for comparative purposes in a trace-element study in the Steamboat Creek subbasin in the North Umpqua Basin (Rinella, 1998). Details regarding and examples of calculation of break-point concentrations can be found in Rinella (1998) and references therein. Note that apparent enrichment of trace elements in streambed sediment in either basin relative to the other basin in this comparative exercise may reflect fundamental differences in basin geology and, in the absence of stronger evidence, cannot be assumed to represent impacts from anthropogenic effects such as mining. Comparison of South Umpqua Basin streambed-sediment data with Willamette Basin data should be viewed with this limitation in mind. This comparison, like the comparison with Canadian guidelines, represents only one way of viewing the data.

Zinc, copper, and cadmium concentrations in streambed sediment from Middle Creek at Silver Butte exceeded Willamette Basin break-point concentrations by roughly two orders of magnitude, a margin sufficiently wide to indicate a highly impacted stream. Zinc, copper, and cadmium concentrations in streambed sediment from Middle Creek near Riddle and at South Fork Middle Creek near Riddle exceeded Willamette Basin break-point concentrations by well over an order of magnitude. Exceedances of at least a few Willamette Basin break-point concentrations were observed at each site; these patterns probably reflect, to at least some degree, differences in the geologic character of the two basins. 
Table 6. Streambed-sediment data

[Fk, fork; Cr, creek; Nr, near; S, south; N, north; Split 1, first of two quality-assurance sample splits; Split 2, second of two quality-assurance sample splits; $\mu \mathrm{g} / \mathrm{g}$, micrograms per gram; or., organic; or.+in., organic plus inorganic; in., inorganic]

\begin{tabular}{|c|c|c|c|c|c|c|c|c|c|c|c|c|}
\hline \multirow[b]{2}{*}{ Constituent } & \multicolumn{2}{|c|}{$\begin{array}{c}\text { Middle Fk } \\
\text { Deadman Cr } \\
\text { Nr Myrtle Cr }\end{array}$} & \multicolumn{2}{|c|}{$\begin{array}{l}\text { Deadman Cr } \\
\text { Nr Milo }\end{array}$} & \multirow{2}{*}{$\begin{array}{c}\text { Days } \\
\text { Cr Nr } \\
\text { Days Cr }\end{array}$} & \multirow{2}{*}{$\begin{array}{c}\text { S Myrtle } \\
\text { Cr Nr } \\
\text { Myrtle Cr }\end{array}$} & \multirow{2}{*}{$\begin{array}{c}\text { N Myrtle } \\
\text { Cr Nr } \\
\text { Myrtle Cr }\end{array}$} & \multirow{2}{*}{$\begin{array}{l}\text { Mitchell } \\
\text { Cr Nr } \\
\text { Canyon- } \\
\text { ville }\end{array}$} & \multirow{2}{*}{$\begin{array}{c}\text { Russell } \\
\text { Cr Nr } \\
\text { Riddle }\end{array}$} & \multirow{2}{*}{$\begin{array}{c}\text { Middle } \\
\text { Cr at } \\
\text { Silver } \\
\text { Butte }\end{array}$} & \multirow{2}{*}{$\begin{array}{c}\text { S Fk } \\
\text { Middle } \\
\text { Cr Nr } \\
\text { Riddle }\end{array}$} & \multirow{2}{*}{$\begin{array}{c}\text { Middle } \\
\text { Cr Nr } \\
\text { Riddle }\end{array}$} \\
\hline & Split 1 & Split 2 & Split 1 & Split 2 & & & & & & & & \\
\hline Aluminum (percent) & 7.4 & 7.1 & 8.5 & 8.3 & 8.3 & 7.6 & 6.8 & 7.5 & 8.4 & 9.4 & 8.5 & 7.7 \\
\hline Antimony $(\mu \mathrm{g} / \mathrm{g})$ & 0.4 & 0.4 & 0.6 & 0.5 & 0.8 & 2 & 0.2 & 0.2 & 0.5 & 5 & 0.3 & 0.9 \\
\hline Barium $(\mu \mathrm{g} / \mathrm{g})$ & 460 & 460 & 610 & 630 & 540 & 460 & 200 & 190 & 410 & 8,400 & 310 & 970 \\
\hline Beryllium $(\mu \mathrm{g} / \mathrm{g})$ & 2 & 2 & 1 & 1 & 1 & 2 & 0.4 & 0.5 & 1 & 2 & 0.9 & 1 \\
\hline Bismuth $(\mu \mathrm{g} / \mathrm{g})$ & $<1$ & $<1$ & $<1$ & $<1$ & $<1$ & $<1$ & $<1$ & $<1$ & $<1$ & $<1$ & $<1$ & $<1$ \\
\hline Carbon, in. (percent) & 0.07 & 0.08 & 0.04 & 0.04 & 0.03 & 0.13 & 0.04 & 0.08 & 0.05 & 0.07 & 0.17 & 0.03 \\
\hline Cerium $(\mu \mathrm{g} / \mathrm{g})$ & 54 & 54 & 46 & 47 & 46 & 55 & 14 & 16 & 36 & 55 & 38 & 33 \\
\hline Chromium $(\mu \mathrm{g} / \mathrm{g})$ & 110 & 100 & 110 & 110 & 160 & 95 & 380 & 79 & 280 & 150 & 84 & 230 \\
\hline Cobalt $(\mu \mathrm{g} / \mathrm{g})$ & 19 & 19 & 22 & 22 & 22 & 20 & 45 & 23 & 33 & 23 & 29 & 29 \\
\hline Copper $(\mu \mathrm{g} / \mathrm{g})$ & 43 & 40 & 58 & 51 & 52 & 43 & 83 & 140 & 86 & 16,000 & 1,400 & 1,500 \\
\hline Europium $(\mu \mathrm{g} / \mathrm{g})$ & 2 & 2 & 2 & 2 & 1 & 2 & $<1$ & 1 & 1 & 4 & 2 & 2 \\
\hline Gallium $(\mu \mathrm{g} / \mathrm{g})$ & 17 & 17 & 18 & 18 & 18 & 19 & 13 & 15 & 18 & 14 & 16 & 15 \\
\hline Lanthanum $(\mu \mathrm{g} / \mathrm{g})$ & 34 & 34 & 28 & 29 & 23 & 32 & 7 & 8 & 18 & 31 & 31 & 20 \\
\hline Lead $(\mu \mathrm{g} / \mathrm{g})$ & 12 & 12 & 10 & 11 & 10 & 11 & 3 & 8 & 9 & 29 & 8 & 11 \\
\hline Lithium $(\mu \mathrm{g} / \mathrm{g})$ & 30 & 30 & 50 & 50 & 40 & 20 & 7 & 20 & 50 & 10 & 20 & 40 \\
\hline Magnesium (percent) & 0.71 & 0.68 & 1.1 & 1.1 & 1.5 & 0.90 & 3.7 & 1.4 & 2.3 & 1.8 & 1.3 & 2.2 \\
\hline Manganese $(\mu \mathrm{g} / \mathrm{g})$ & 1,800 & 1,800 & 980 & 980 & 1,000 & 1,600 & 2,600 & 1,300 & 1,000 & 920 & 3,600 & 1,000 \\
\hline Mercury $(\mu \mathrm{g} / \mathrm{g})$ & 0.09 & 0.10 & 0.41 & 0.59 & 0.07 & 0.07 & 0.07 & 0.28 & 0.14 & 0.61 & 0.12 & 0.17 \\
\hline Molybdenum $(\mu \mathrm{g} / \mathrm{g})$ & 0.8 & 0.8 & 0.7 & 0.6 & 0.7 & 0.9 & $<.5$ & 0.6 & 0.7 & 3 & $<.5$ & 0.9 \\
\hline Neodymium $(\mu \mathrm{g} / \mathrm{g})$ & 39 & 39 & 29 & 30 & 24 & 33 & 10 & 13 & 21 & 48 & 39 & 24 \\
\hline Nickel $(\mu \mathrm{g} / \mathrm{g})$ & 44 & 43 & 58 & 59 & 51 & 30 & 320 & 67 & 190 & 100 & 62 & 170 \\
\hline Niobium $(\mu \mathrm{g} / \mathrm{g})$ & 4 & 4 & 7 & 5 & 9 & 10 & $<4$ & $<4$ & $<4$ & $<4$ & $<4$ & 5 \\
\hline Phosphorus (percent) & 0.092 & 0.089 & 0.10 & 0.096 & 0.095 & 0.081 & 0.072 & 0.12 & 0.085 & 0.063 & 0.10 & 0.086 \\
\hline Potassium (percent) & 0.69 & 0.66 & 0.95 & 0.94 & 1.1 & 0.80 & 0.18 & 0.24 & 0.82 & 0.42 & 0.54 & 0.78 \\
\hline
\end{tabular}


Table 6. Streambed-sediment data-Continued

[Fk, fork; Cr, creek; Nr, near; S, south; N, north; Split 1, first of two quality-assurance sample splits; Split 2, second of two quality-assurance sample splits; $\mu \mathrm{g} / \mathrm{g}$, micrograms per gram; or., organic; or.+in., organic plus inorganic; in., inorganic]

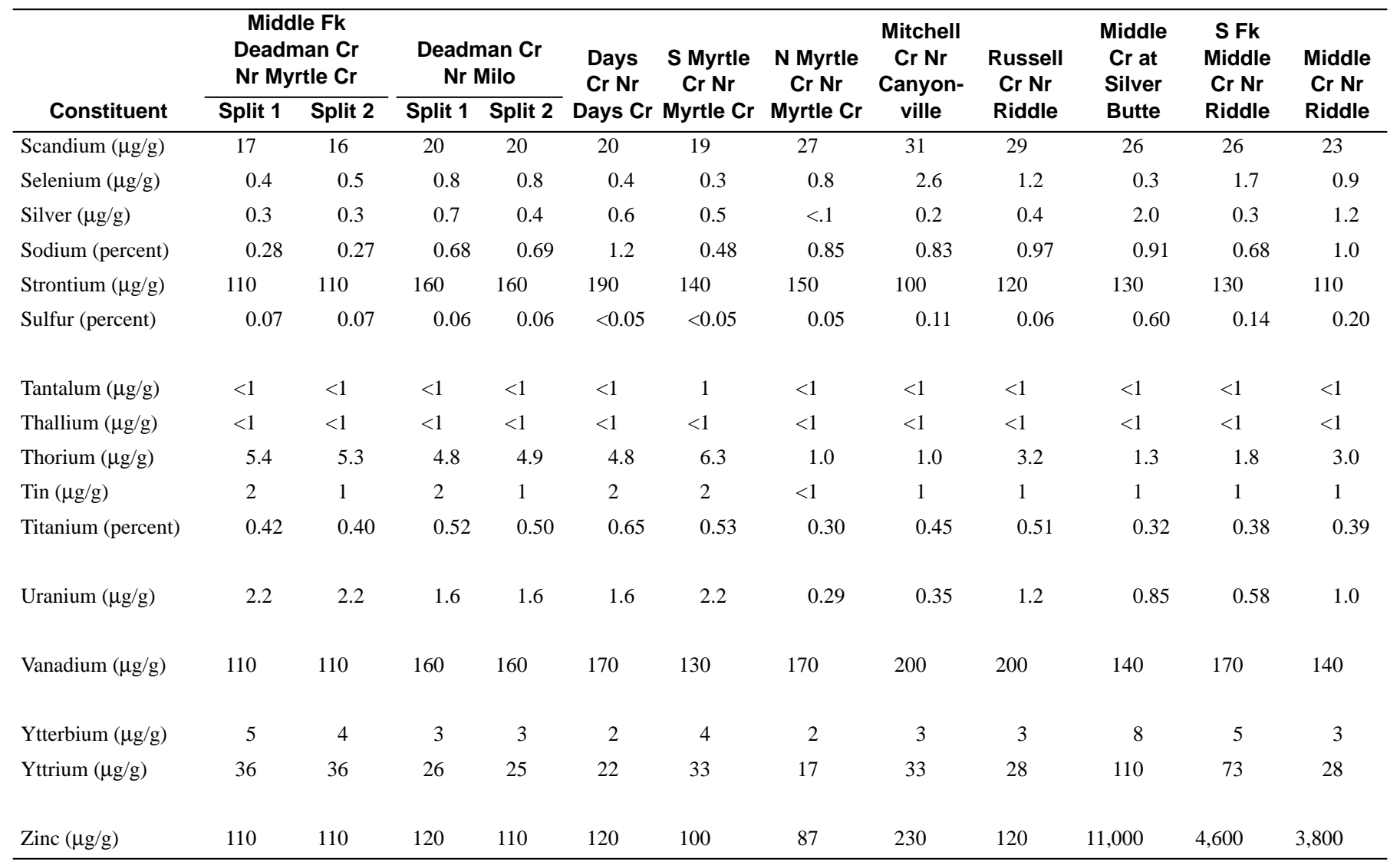

\section{SUMMARY}

This report presents results of a 1998 reconnaissance investigation of inorganic chemical characteristics of water and streambed sediment in selected South Umpqua River tributaries. Ten sites on small streams draining areas containing natural ore deposits and/or mining sites were sampled.

In aqueous samples, values of $\mathrm{pH}$ were near neutral to slightly alkaline, and most trace-element concentrations were low. However, some elevated concentrations of zinc, copper, and cadmium were observed. Concentrations of zinc $(1,450 \mu \mathrm{g} / \mathrm{L})$, copper $(97 \mu \mathrm{g} / \mathrm{L})$, and cadmium $(8 \mu \mathrm{g} / \mathrm{L})$ for Middle Creek at Silver Butte all exceeded U.S. Environmental Protection Agency (USEPA) criterion continuous concentration (CCC) guidelines for the protection of aquatic life. The concentration of zinc $(134 \mu \mathrm{g} / \mathrm{L})$ for Middle Creek near Riddle also exceeded the USEPA CCC guideline.

Mirroring patterns observed in aqueous samples, streambed-sediment concentrations of zinc, copper, and cadmium for Middle Creek at Silver Butte were elevated relative to concentrations at other sampled sites. On a dry-weight percentage basis, streambed sediment at this site was greater than 1 percent copper and 1 percent zinc. Concentrations of other trace elements (for example, lead and mercury) also were elevated at this site compared with other sites.

Zinc, copper, and cadmium concentrations in streambed sediment from Middle Creek at Silver Butte exceeded Canadian sediment quality guidelines for the protection of aquatic life by approximately two orders of magnitude. Concentrations of zinc, copper, and cadmium in streambed sediment exceeded Canadian guidelines by well over one order of magnitude at Middle Creek near Riddle and at South Fork Middle Creek near Riddle.

The dissolved aqueous load of zinc (operationally defined as the product of stream discharge and zinc concentration in filtered water) carried by Middle Creek along the stretch between the upper site (Middle Creek at Silver Butte) and the lower site (Middle Creek near Riddle) decreased from about 0.5 pounds per day at the upper site to 0.2 pounds per day at the lower site. Removal of about 0.3 pounds per day of zinc from solution (solid-phase precipitation and/or adsorption) between the upper and lower sites on Middle Creek evidently was occurring at the time of sampling. 
Table 7. Comparison between streambed-sediment concentrations and Canadian sediment quality guidelines for the protection of aquatic life (exceedances of guidelines in bold type)

[Streambed-sediment concentrations in units of micrograms per gram; Fk, fork; Cr, creek; Nr, near; S, south; N, north; Split 1, first of two quality-assurance sample splits; Split 2, second of two quality-assurance sample splits]

\begin{tabular}{|c|c|c|c|c|c|c|c|c|c|c|c|c|c|}
\hline Constituent & $\begin{array}{l}\text { Canadian } \\
\text { sediment } \\
\text { quality } \\
\text { guidelines } \\
\text { for the } \\
\text { protection } \\
\text { of aquatic } \\
\text { life }\end{array}$ & \multicolumn{2}{|c|}{$\begin{array}{c}\text { Middle Fk } \\
\text { Deadman Cr } \\
\text { Nr Myrtle Cr }\end{array}$} & \multicolumn{2}{|c|}{$\begin{array}{c}\text { Deadman } \mathrm{Cr} \\
\text { Nr Milo }\end{array}$} & $\begin{array}{c}\text { Days } \\
\text { Cr Nr } \\
\text { Days Cr }\end{array}$ & $\begin{array}{c}\text { S Myrtle } \\
\text { Cr Nr } \\
\text { Myrtle Cr }\end{array}$ & $\begin{array}{l}\text { N Myrtle } \\
\text { Cr Nr } \\
\text { Myrtle Cr }\end{array}$ & $\begin{array}{l}\text { Mitchell } \\
\text { Cr Nr } \\
\text { Canyon- } \\
\text { ville }\end{array}$ & $\begin{array}{c}\text { Russell } \\
\text { Cr Nr } \\
\text { Riddle }\end{array}$ & $\begin{array}{c}\text { Middle } \\
\text { Cr at } \\
\text { Silver } \\
\text { Butte }\end{array}$ & $\begin{array}{c}\text { S Fk } \\
\text { Middle } \\
\text { Cr Nr } \\
\text { Riddle }\end{array}$ & $\begin{array}{c}\text { Middle } \\
\mathrm{Cr} \mathrm{Nr} \\
\text { Riddle }\end{array}$ \\
\hline Cadmium & 0.6 & 0.3 & 0.3 & 0.3 & 0.3 & 0.2 & 0.2 & 0.2 & 0.6 & 0.3 & 30 & 17 & 17 \\
\hline Chromium & 37.3 & 110 & 100 & 110 & 110 & 160 & 95 & 380 & 79 & 280 & 150 & 84 & 230 \\
\hline Mercury & 0.17 & 0.09 & 0.10 & 0.41 & 0.59 & 0.07 & 0.07 & 0.07 & 0.28 & 0.14 & 0.61 & 0.12 & 0.17 \\
\hline Zinc & 123 & 110 & 110 & 120 & 110 & 120 & 100 & 87 & 230 & 120 & 11,000 & 4,600 & 3,800 \\
\hline
\end{tabular}

Table 8. Comparison between streambed-sediment concentrations from this study and break-point values for streambed sediment in the Willamette Basin

[Willamette Basin break-point values from Rinella (1998) as discussed in text; exceedances of Willamette Basin break-point values are not necessarily representative of enriched conditions; streambed-sediment concentrations in units of micrograms per gram; Fk, fork; Cr, creek; Nr, near; S, south; N, north; Split 1, first of two quality-assurance sample splits; Split 2, second of two quality-assurance sample splits]

\begin{tabular}{|c|c|c|c|c|c|c|c|c|c|c|c|c|c|}
\hline \multirow[b]{2}{*}{ Constituent } & \multirow{2}{*}{$\begin{array}{l}\text { Willamette } \\
\text { Basin } \\
\text { break-point } \\
\text { values }\end{array}$} & \multicolumn{2}{|c|}{$\begin{array}{c}\text { Middle Fk } \\
\text { Deadman Cr } \\
\text { Nr Myrtle Cr }\end{array}$} & \multicolumn{2}{|c|}{$\begin{array}{c}\text { Deadman Cr } \\
\text { Nr Milo }\end{array}$} & \multirow{2}{*}{$\begin{array}{c}\text { Days } \\
\text { Cr Nr } \\
\text { Days Cr }\end{array}$} & \multirow{2}{*}{$\begin{array}{c}\text { S Myrtle } \\
\text { Cr Nr } \\
\text { Myrtle Cr }\end{array}$} & \multirow{2}{*}{$\begin{array}{c}\text { N Myrtle } \\
\text { Cr Nr } \\
\text { Myrtle Cr }\end{array}$} & \multirow{2}{*}{$\begin{array}{l}\text { Mitchell } \\
\text { Cr Nr } \\
\text { Canyon- } \\
\text { ville }\end{array}$} & \multirow{2}{*}{$\begin{array}{c}\text { Russell } \\
\text { Cr Nr } \\
\text { Riddle }\end{array}$} & \multirow{2}{*}{$\begin{array}{c}\text { Middle } \\
\text { Cr at } \\
\text { Silver } \\
\text { Butte }\end{array}$} & \multirow{2}{*}{$\begin{array}{c}\text { S Fk } \\
\text { Middle } \\
\text { Cr Nr } \\
\text { Riddle }\end{array}$} & \multirow{2}{*}{$\begin{array}{c}\text { Middle } \\
\text { Cr Nr } \\
\text { Riddle }\end{array}$} \\
\hline & & Split 1 & Split 2 & Split 1 & Split 2 & & & & & & & & \\
\hline Antimony & 1.3 & 0.4 & 0.4 & 0.6 & 0.5 & 0.8 & 2 & 0.2 & 0.2 & 0.5 & 5 & 0.3 & 0.9 \\
\hline Chromium & 100 & 110 & 100 & 110 & 110 & 160 & 95 & 380 & 79 & 280 & 150 & 84 & 230 \\
\hline Cobalt & 30 & 19 & 19 & 22 & 22 & 22 & 20 & 45 & 23 & 33 & 23 & 29 & 29 \\
\hline Copper & 50 & 43 & 40 & 58 & 51 & 52 & 43 & 83 & 140 & 86 & 16,000 & 1,400 & 1,500 \\
\hline Lead & 30 & 12 & 12 & 10 & 11 & 10 & 11 & 3 & 8 & 9 & 29 & 8 & 11 \\
\hline Silver & 0.3 & 0.3 & 0.3 & 0.7 & 0.4 & 0.6 & 0.5 & $<.1$ & 0.2 & 0.4 & 2.0 & 0.3 & 1.2 \\
\hline Zinc & 200 & 110 & 110 & 120 & 110 & 120 & 100 & 87 & 230 & 120 & 11,000 & 4,600 & 3,800 \\
\hline
\end{tabular}


Zinc solubility is $\mathrm{pH}$-dependent, and zinc adsorbed onto solid-phase surfaces tends to desorb with a decrease in $\mathrm{pH}$. Thus, a sufficient decrease in $\mathrm{pH}$ could have had the effect of shifting the dynamics between solid and aqueous phases towards release of zinc to solution in Middle Creek. The implication is that at least two potentially significant sources of zinc may exist in Middle Creek: (1) the upstream source(s) producing the observed high aqueous zinc concentrations and (2) the streambed sediment (zinc-bearing solid phases and/or adsorbed zinc).

\section{REFERENCES CITED}

Arbogast, B.F., ed., 1996, Analytical methods manual for the Mineral Resource Surveys Program, U.S. Geological Survey: U.S. Geological Survey Open-File Report 96-525, $248 \mathrm{p}$.

Ball, J.W., and Nordstrom, D.K., 1991, User's manual for WATEQ4F, with revised thermodynamic data base and test cases for calculating speciation of major, trace, and redox elements in natural waters: U.S. Geological Survey Open-File Report 91-183, 189 p.

Brick, C.M., and Moore, J.N., 1994, Diurnal mobility and partitioning of manganese, iron, zinc and copper in the Clark Fork River, Montana [abstract]: Eos, Transactions of the American Geophysical Union, v. 75, no. 44, Fall Meeting Supplement, p. 241-242.

Briggs, P.H., and Meier, A.L., 1999, The determination of forty-two elements in geological materials by inductively coupled plasma-mass spectrometry: U.S. Geological Survey Open-File Report 99-166, 15 p.

Environment Canada, 1998, Canadian sediment quality guidelines; retrieved May 19, 1999, from URL<http://www.ec.gc.ca/ceqg-rcqe/sediment.htm>.

Faires, L.M., 1993, Methods of analysis by the U.S. Geological Survey National Water Quality LaboratoryDetermination of metals in water by inductively coupled plasma-mass spectrometry: U.S. Geological Survey Open-File Report 92-634, 28 p.

Farrar, J.W., and Long, H.K., 1997, Report on the U.S. Geological Survey's evaluation program for standard reference samples distributed in September 1996: T-143 (trace constituents), T-145 (trace constituents), M-140 (major constituents), N-51 (nutrient constituents), $\mathrm{N}-52$ (nutrient constituents), P-27 (low ionic strength constituents), and Hg-23 (mercury): U.S. Geological Survey Open-File Report 97-20, 145 p.

Fishman, M.J., 1993, Methods of analysis by the U.S. Geological Survey National Water Quality LaboratoryDetermination of inorganic and organic constituents in water and fluvial sediments: U.S. Geological Survey Open-File Report 93-125, 217 p.

Fishman, M.J., and Friedman, L.C., eds., 1989, Methods for determination of inorganic substances in water and fluvial sediments: U.S. Geological Survey Techniques of WaterResources Investigations, book 5, chap. A1, 545 p.

Hem, J.D., 1972, Chemistry and occurrence of cadmium and zinc in surface water and groundwater: Water Resources Research, v. 8, p. 661-679.

Horowitz, A.J., and Elrick, K.A., 1987, The relation of stream sediment surface area, grain size and composition to trace element chemistry: Applied Geochemistry, v. 2, p. 437-451.

Jones, S.R., and Garbarino, J.R., 1999, Methods of analysis by the U.S. Geological Survey National Water Quality Laboratory-Determination of arsenic and selenium in water and sediment by graphite furnace/atomic absorption spectrometry: U.S. Geological Survey Open-File Report 98-639, 39 p.

Klein, Cornelis, and Hurlbut, C.S., Jr., 1985, Manual of Mineralogy, after James D. Dana (20th ed.): New York, John Wiley \& Sons, 596 p.

Orr, E.L., Orr, W.N., and Baldwin, E.M., 1992, Geology of Oregon (4th ed.): Dubuque, Iowa, Kendall/Hunt Publishing Company, $254 \mathrm{p}$.

Pritt, J.W., and Raese, J.W., eds., 1995, Quality assurance/ quality control manual-National Water Quality Laboratory: U.S. Geological Survey Open-File Report 95-443, 35 p.

Rantz, S.E., and others, 1982, Measurement and computation of streamflow: U.S. Geological Survey Water-Supply Paper 2175, 2 vol., 631 p.

Rinella, F.A., 1998, Major-ion, nutrient, and trace-element concentrations in the Steamboat Creek Basin, Oregon, 1996: U.S. Geological Survey Water-Resources Investigations Report 98-4105, 31 p.

Shelton L.R., 1994, Field guide for collecting and processing stream-water samples for the National Water-Quality Assessment Program: U.S. Geological Survey Open-File Report 94-455, 42 p.

Shelton, L.R., and Capel, P.D., 1994, Guidelines for collecting and processing samples of streambed sediment for analysis of trace elements and organic contaminants for the National Water-Quality Assessment Program: U.S. Geological Survey Open-File Report 94-458, 20 p.

Shenon, P.J., 1933, Copper deposits in the Squaw Creek and Silver Peak Districts and at the Alameda Mine, southwestern Oregon, with notes on the Pennell and Farmer and Banfield prospects: U.S. Geological Survey Circular 2, $35 \mathrm{p}$.

Stumm, Werner, and Morgan, J.J., 1996, Aquatic chemistry (3d ed.): New York, John Wiley and Sons, 1022 p.

U.S. Environmental Protection Agency, 1997, The incidence and severity of sediment contamination in surface waters of the United States: EPA 823-R-97-006, [variously paged]. 1998, National Recommended Water Quality Criteria; republication: Federal Register, v. 63, no. 237, December 10, 1998, p. 68354-68364. 



\section{APPENDIX}

Table A1. Values of hardness for aqueous samples from sites sampled, and corresponding U.S. Environmental Protection Agency criterion continuous concentration (CCC) guidelines for the protection of aquatic life (U.S. Environmental Protection Agency, 1998) [CCCs for cadmium, chromium III, copper, lead, nickel, and zinc are functions of hardness (see U.S. Environmental Protection Agency, 1998); Fk, fork; Cr, creek; Nr, near; S, south; N, north; mg/L, milligrams per liter; $\mu \mathrm{g} / \mathrm{L}$, micrograms per liter]

\begin{tabular}{|c|c|c|c|c|c|c|c|c|c|c|}
\hline Constituent & $\begin{array}{c}\text { Middle Fk } \\
\text { Deadman } \\
\text { Cr Nr } \\
\text { Myrtle Cr }\end{array}$ & $\begin{array}{c}\text { Deadman } \\
\text { Cr Nr } \\
\text { Milo }\end{array}$ & $\begin{array}{c}\text { Days } \\
\text { Cr Nr } \\
\text { Days Cr }\end{array}$ & $\begin{array}{c}\text { S Myrtle } \\
\text { Cr Nr } \\
\text { Myrtle Cr }\end{array}$ & $\begin{array}{c}\text { N Myrtle } \\
\text { Cr Nr } \\
\text { Myrtle Cr }\end{array}$ & $\begin{array}{c}\text { Mitchell } \\
\text { Cr Nr } \\
\text { Canyon- } \\
\text { ville }\end{array}$ & $\begin{array}{c}\text { Russell } \\
\text { Cr Nr } \\
\text { Riddle }\end{array}$ & $\begin{array}{c}\text { Middle } \\
\text { Cr at } \\
\text { Silver } \\
\text { Butte }\end{array}$ & $\begin{array}{c}\text { S Fk } \\
\text { Middle } \\
\text { Cr Nr } \\
\text { Riddle }\end{array}$ & $\begin{array}{c}\text { Middle } \\
\text { Cr Nr } \\
\text { Riddle }\end{array}$ \\
\hline $\begin{array}{l}\text { Hardness } \\
\left(\mathrm{mg} / \mathrm{L} \text { as } \mathrm{CaCO}_{3}\right)\end{array}$ & 30 & 51 & 69 & 22 & 82 & 120 & 71 & 190 & 66 & 110 \\
\hline Aluminum $(\mu \mathrm{g} / \mathrm{L})$ & 87 & 87 & 87 & 87 & 87 & 87 & 87 & 87 & 87 & 87 \\
\hline Arsenic III $(\mu \mathrm{g} / \mathrm{L})$ & 150 & 150 & 150 & 150 & 150 & 150 & 150 & 150 & 150 & 150 \\
\hline Cadmium $(\mu \mathrm{g} / \mathrm{L})$ & 0.92 & 1.36 & 1.70 & 0.73 & 1.93 & 2.56 & 1.74 & 3.60 & 1.65 & 2.40 \\
\hline Chromium III ( $\mu \mathrm{g} / \mathrm{L})$ & 27.65 & 42.70 & 54.69 & 21.45 & 63.00 & 86.05 & 55.99 & 125.37 & 52.74 & 80.13 \\
\hline Chromium VI $(\mu \mathrm{g} / \mathrm{L})$ & 11 & 11 & 11 & 11 & 11 & 11 & 11 & 11 & 11 & 11 \\
\hline Copper $(\mu \mathrm{g} / \mathrm{L})$ & 3.20 & 5.04 & 6.52 & 2.46 & 7.56 & 10.47 & 6.68 & 15.50 & 6.28 & 9.72 \\
\hline Iron $(\mu \mathrm{g} / \mathrm{L})$ & 1,000 & 1,000 & 1,000 & 1,000 & 1,000 & 1,000 & 1,000 & 1,000 & 1,000 & 1,000 \\
\hline Lead $(\mu \mathrm{g} / \mathrm{L})$ & 0.66 & 1.20 & 1.68 & 0.47 & 2.03 & 3.07 & 1.73 & 5.02 & 1.60 & 2.79 \\
\hline Nickel $(\mu \mathrm{g} / \mathrm{L})$ & 18.78 & 29.42 & 37.99 & 14.45 & 43.97 & 60.68 & 38.92 & 89.51 & 36.59 & 56.37 \\
\hline Selenium $(\mu \mathrm{g} / \mathrm{L})$ & 4.61 & 4.61 & 4.61 & 4.61 & 4.61 & 4.61 & 4.61 & 4.61 & 4.61 & 4.61 \\
\hline Zinc $(\mu \mathrm{g} / \mathrm{L})$ & 42.59 & 66.78 & 86.27 & 32.75 & 99.85 & 137.87 & 88.38 & 203.51 & 83.08 & 128.08 \\
\hline
\end{tabular}


